\title{
FEMINISM AND/IN THE/ITS PLURAL
}

\author{
Begonya Saez Tajafuerce* \\ (D) https: / / orcid.org/0000-0001-7326-4478
}

\begin{abstract}
In recent times, Feminism has been declared a mass phenomenon, as if it thereby was attributed a plural character. Yet, what kind of plurality is at stake for the Mass as a subject? According to the philosophical notion of das Man, the Mass serves indifference, and it therefore stands as the paradigmatic subject of neoliberalism, fascism, and right-wing populism. The logic of the Mass is the logic of the One. Yet difference makes operative another logic, namely the logic of Plurality, a relational logic that allows for the new, the unexpected, and the improbable. Given its radically material and non-discursive complex character, the Body actualizes this true transformation by enacting sexual difference. By taking the Body into account, that is, by taking difference specifically into account, both in ontological as well as in epistemological and in ethico-political terms, Feminism might become an antidote to the totalitarian logic of the One.
\end{abstract}

Keywords: Feminism, neoliberalism, plurality, sexual difference, relationality.

\section{O Feminismo e/no/seu plural}

Recentemente, o Feminismo foi declarado um fenómeno de massas e parece que, dessa forma, se lhe atribui um caráter plural. Mas de que plural se fala quando o sujeito são as massas? De acordo com a noção filosófica de das Man, a Massa serve a indiferença e, portanto, assume o papel de sujeito paradigmático do neoliberalismo, do fascismo e do populismo de direita. A lógica da Massa é a Lógica do Um. Por contraste, a diferença torna outra lógica operacional, a lógica do Plural, uma lógica relacional que possibilita o que é novo, o inesperado e o improvável. Dado o seu caráter complexo, radicalmente material e não discursivo, o Corpo concretiza essa verdadeira transformação através da diferença sexual. Levando-se em conta o Corpo, isto é, tendo especificamente em conta a diferença, tanto em termos ontológicos quanto epistemológicos e ético-políticos, o feminismo pode-se tornar o antídoto contra a lógica totalitária do Um.

Palavras-chave: Feminismo, neoliberalismo, pluralidade, diferença sexual, lógica relacional.

\section{Resumen}

\section{El Feminismo y/en el/su plural}

Recientemente, el Feminismo ha sido declarado fenómeno de masas y pareciera que de ese modo se le atribuye un carácter plural. Pero, ¿de qué plural se hace cargo la masa

Department of Philosophy at Universitat Autònoma de Barcelona, 08193 Bellaterra, Barcelona, Spain.

Postal address: Edifici B, Carrer de la Fortuna, despatx B7/110, Campus de la UAB, 08193

Bellaterra, Barcelona, Spain.

Electronic address: Begonya.Saez@uab.cat 
como sujeto? A tenor de la noción filosófica de das Man, la Masa atiende a la indiferencia y por eso asume el papel de sujeto paradigmático del Neoliberalismo, del Fascismo y del Populismo de derechas. La lógica de la Masa es la Lógica del Uno. En cambio, la diferencia hace operativa otra lógica, a saber, la lógica del Plural, una lógica relacional que da lugar a lo nuevo, a lo inesperado y a lo improbable. Dado su complejo carácter radicalmente material y no discursivo, el cuerpo actualiza esta verdadera transformación mediante la diferencia sexual. Tomando en consideración el cuerpo, tomando en consideración la diferencia en su especificidad, tanto en términos ontológicos como también epistemológicos y ético-políticos, el feminismo puede llegar a ser el antídoto contra la lógica totalitaria del Uno.

Palabras clave: Feminismo, Neoliberalismo, pluralidad, diferencia sexual, lógica relacional.

In recent times, Feminism has been insistently declared a mass phenomenon in a wide variety of social and cultural milieux. Yet, what does such affirmation entail as regards the ethical and political challenges Feminism faces nowadays? Likewise, how does it determine not only the present but definitively also the future of Feminism in our capitalist world?

In order to address these questions, this paper aims at complexity. Already its title bears witness to complexity or, rather, to a specific complexity, conveying the need of stressing the importance and necessity of not simplifying Feminism inasmuch as simplification has proved to be one among the most efficient ideologically staged neoliberal political and economic strategies globally.

In this context, the reason I encourage complexity for Feminism and for any theoretical approach to it, is that complexity brings about an ethical and political opening, which Feminism should take on and hold on to. Hence, the main idea I would like to convey is this: let us not simplify Feminism. Or, in other words, let us not assume and comply with the discursive ideological strategy of simplification, the primary subject of which is indeed the Mass. At this point, I need to make clear that I shall render operative this category, the Mass, as one of the contemporary shapes of subjectivity, referring to a concrete philosophical tradition, entitled by Kierkegaard and Heidegger. They both discuss subjectivity in terms of the Mass or, in Heidegger's German, the well-known and impersonal das Man, or simply «man» (or «one») in English.

In $\S 27$ of Being and Time, devoted to the phenomenological analysis of Dasein as the Self in everyday life, Heidegger states that, in order to avoid the leveling dictatorship of das Man, care is required. Care is what makes being or Sein a Dasein. It is care which singularizes being. The $D a$ of Dasein designates therefore an affective condition of the presence of being. It does not simply designate presence or, to be even more precise, it does not designate presence simply understood in spatial and temporal terms. What is at stake here is not being as such - which would entail an ontological, ethical, and epistemological simplification -, but in 
more complex terms, what is at stake here is indeed the singularization of being by means of care, and not any kind of care but specifically «the care for difference - a distance - in front of the others.» This, I repeat, «the care for a difference in front of the others,» is what is required for being to be or, rather, to become, or even to become singularized as Dasein.

Now, let us go back to the consideration of Feminism as a mass phenomenon. In my understanding, Feminism consists, in a structural way, in desiring and daring to denounce simplification precisely as a discursive ideological strategy, which is that of das Man, and in taking hold of complexity as a modus operandi. A concrete example of this among many is diffraction, which is the discursive method both Donna Haraway and Karen Barad, situated in different disciplines, biology and quantum physics respectively, propose in an epistemological context in order to challenge reflection or its counterpart, refraction. Diffraction is concerned with difference and specifically with difference as a critical tool, as a method which allows for dealing with relationality as the main onto-ethico-epistemological condition. Whereas reflection tends to level knowledge, both its procedures and its results, the goal of diffraction is instead precisely to map the effects of difference or, in more technical terms, the effects of the material shaping of difference in, for instance, interference or interruption or suspension or the accidental or the event in, say, living processes.

Both the Dasein's care as existential structure and Haraway's and Barad's diffraction as a critical tool imply affection, and affection, I assert, is fundamentally linked to complexity. I will soon develop the issue of Feminism and affection. Yet, before that I would like to underline the idea I just mentioned, namely, that Feminism is and needs to be devoted to complexity as well as to reviling simplification. Feminism is and needs to be an antidote to simplification, and this implies that its relation to the Mass must be challenged, because the Mass or das Man, man or the «one», cannot fulfill such a task. Why is that so?

Why can the Mass not be - and, in my view, should not be - the subject of Feminism? I will maintain that there are three kinds of reasons for the Mass to be an inadequate or even an illegitimate subject of Feminism: there are ontological, epistemological, and ethico-political reasons. These reasons concern three existential axes, namely, being, knowledge, and action in the context of Feminism, and it concerns likewise the relations that we universally and singularly at once establish between them in order to bring consistency to our lives and world both in individual and in collective terms.

There is no doubt that today Feminism is a massive movement. Yet, is it a mass movement? This is another way of asking the question of the adequacy and of the legitimacy of the Mass as the subject of Feminism. In correspondence to the three existential axes mentioned above - being, knowledge, and action - I want now to point to three aspects that refer to the very nature of the Mass as a subject, namely: (1) the One, (2) Certainty, and (3) Perfection. Although I shall focus on the 
first aspect, that is, on the ontological determination of the Mass as the One, it is important to keep in mind that all three aspects are fundamentally interconnected, and that they support one another because they are structurally bound. They make the Mass, as apparatus, operative in the context of modern neoliberal states.

Thus, the One, Certainty, and Perfection express the main qualities of the Mass when comprehended from an ontological, epistemological, and ethicopolitical perspective, that is, from the point of view of our threefold existential axiology: being, knowledge, and action. This means that (1) the Mass is the One, fully and wholly constituted in terms of identity, and that it does not entail any reference to either alterity or difference. There is no Other in the horizon of the One. There is no Other for the One. Concomitantly, (2) the Mass does not engage in any kind of self-reflective procedure regarding the conclusions it reaches. The Mass does not step back to reconsider the outcome of any research it undertakes, and neither does it hesitate to apply the results it validates, and of course it does not doubt or question what it knows in the context of a radical subject-object relationship. Nothing breaks the Certainty of the Mass. (3) As to the third quality of the Mass as a subject, which refers to action from the point of view of Perfection, it implies that, as a matter of fact, no real action is taken by the Mass, since when perfection is given, no change applies. Hannah Arendt, who has elaborated on action from an ontological as well as from an ethico-political perspective in contemporary terms, clearly states that action - besides labor and work, the other two pillars of the human vita activa - refers to plurality. She makes clear that plurality is the condition for all political life as well as for the actualization of the capacity of freedom understood as the capacity of bringing about something radically new, something unexpected, a true beginning as a break. This is the reason why natality is the paradigm chosen by Arendt to explain action as the actualization of freedom. I shall come back to plurality below.

Action makes a difference also in the sense that it differentiates humans as such. Therefore, Arendt claims, true transformations - as opposed to «mere changes» - or «revolutions are the only political events which confront us directly and inevitably with the problem of beginning» (Arendt 1990, 21). Hence, in her view, which I fully subscribe here, action implies that initiative is taken to bring about that which is new understood as the improbable in life and in the world. In this respect, she writes: «It is the nature of beginning that something new is started which cannot be expected from whatever may have happened before. This character of startling unexpectedness is inherent in all beginnings and in all origins» (Arendt 1989, 178), and she specifies:

The fact that man is capable of action means that the unexpected can be expected from him, that he is able to perform what is infinitely improbable. And this again is possible only because each man is unique, so that with each birth something uniquely new comes into the world. (Arendt 1989, 178) 
The Mass lacks the capacity of bringing about that which is new, that is, it lacks the capacity for action - as well as the capacity for freedom - because it lacks uniqueness or, in other words, because it lacks singularity. The Mass is the One and this means that it entirely submits to the universal. This is precisely what structurally explains the banality of evil. The Mass is and remains indifferent to the question «Who are you»? (Arendt 1989, 178).

Forged in the ontological terms of the One, in the epistemological terms of Certainty, and in the ethico-political terms of Perfection, we see the Mass time and again operating in neoliberal configurations, in fascist congregations, and in rightwing populism. The subject underlying these forms of conservatism and, accordingly, of patriarchal capitalism, the subject in which they are grounded and literally find support is the Mass conforming to the qualities I have just mentioned. I recall Heidegger's reference to the «leveling dictatorship» of das Man.

What seems crucial here is that, as an embodiment of the One, as shaped in Certainty, as granted by Perfection, and as legitimated by all three, the Mass is and remains a static subject. This entails that the Mass does not allow for movement, for change, for transformation, for revolution. It is rather contrary to it all. It embodies, shapes, and grants the impossibility of it all or the impossibility of that what is new and unexpected, in Arendt's words. The Mass is the subject of any kind of totalitarianism. Therefore, it necessarily stands and falls as the paradigmatic subject of neoliberalism, fascism, and right-wing populism. Those are names for ontological, epistemological, and ethico-political staticism. Feminism, on the contrary, is and remains a movement, and I emphasize «movement» here. So the logic of Feminism should by no means coincide with, tend to or imitate the static logic of the Mass. Feminism does rather make this logic evident in everyday life ways of being, knowing, and acting, and opposes it.

Therefore, I insist, let us not simplify Feminism. Let us not reduce it to the One, to Certainty, and to Perfection. Let us instead dare complexity, and take on the challenge of Plurality, of Indetermination, and of Affection.

Plurality, Indetermination, and Affection are the conditio sine qua non of Feminism in our times and just like the One, Certainty, and Perfection, their counterparts, they are also fundamentally interconnected and they support one another because they too are structurally bound. The structure they conform to is relationality, understood as the ontological, epistemological, and ethico-political conditio sine qua non of existence. Hannah Arendt speaks of «the fact that men, not Man, live on the earth and inhabit the world» (Arendt 1989, 7). Yet, relationality is and needs to be at once a universal and a singular conditio sine qua non for existence, «because we are all the same, that is, human, in such a way that nobody is ever the same as anyone else who ever lived, lives, or will live» (Arendt 1989, 8). Therefore, relationality entails difference - or Plurality in Arendt's terminology. It entails a consideration of difference. It entails an observance of difference. In other words, 
recalling again Heidegger, relationality entails «the care for difference - in front of the others» as the conditio sine qua non to become singularized as a Dasein instead of just - indifferently - identified as the Mass.

Being women together was not enough. We were different. Being gay-girls together was not enough. We were different. Being Black together was not enough. We were different. Being Black women together was not enough. We were different. Being Black dykes together was not enough. We were different. Each of us had our own needs and pursuits, and many different alliances. Self-preservation warned some of us that we could not afford to settle for one easy definition, one narrow individuation of self (...) It was a while before we came to realize that our place was the very house of difference rather [than] the security of any one particular difference. (Lorde 1985, 226)

What does it imply for Feminism to take care of difference - in front of the others or, more specifically, to structurally take care of difference - in front of the others? Strictly speaking, what does it imply for Feminism to take care of difference not simply as an object, as a phenomenon, as a fact, that is, as applying inequality in all domains of existence, but to take care of difference as an ontological, epistemological, and ethico-political condition of Feminism itself? What does it imply for Feminism to conform to difference? I suggest that one way to take on these questions is by referring to plurality in the context of the threefold existential axis I just mentioned: Plurality, Indetermination, and Affection.

In what follows, I will pursue a brief approximation to the complexity that concerns Feminism by referring to the way in which it deals with difference as plurality. Feminism is and should not be one Feminism but plural Feminisms. Feminism is and should be plural as opposed to the One. Engaging with difference in terms of plurality should determine not only the being of Feminism but equally the way in which Feminism deals with knowledge via indetermination and the way it engages in action via affection.

In this respect, taking into account this complexity as structural, the question, in Arendtian terms, is how might Feminism not only allow but firmly stand as the possibility for that which is new, the unexpected, the improbable to become, or how might Feminism allow and firmly stand as the possibility for an ontological, epistemological, and ethico-political opening. How might Feminism take on this fundamental task understood as an antidote to the task constantly fulfilled by the Mass? We know that this task requires Plurality since only Plurality allows and firmly stands as the possibility for movement, change, transformation, and indeed revolution, thus not «a mere change».

Now, to what extent is Feminism willing to acknowledge itself in difference? To what extent is Feminism committed to the care for difference - in front of others? To what extent is Feminism devoted to claiming difference as modus operandi? To what extent is Feminism ready to split into Feminisms and give up the One for 
good? These questions might seem banal to a certain point, or even anachronistic. We all do recall that two and a half decades ago, in 1993, Linda Alcoff and Elizabeth Potter edited Feminist Epistemologies. Thinking Gender. In their introductory article to the volume, titled «When Feminisms Intersect Epistemology», they state:

For feminists, the purpose of epistemology is not only to satisfy intellectual curiosity, but also to contribute to an emancipatory goal: the expansion of democracy in the production of knowledge. This goal requires that our epistemologies make it possible to see how knowledge is authorized and who is empowered by it. It follows that feminist epistemologies should be self-reflexive, able to reveal their own social grounds, a revelation made all the more urgent because academic feminists are in a contradictory social position, seeking fundamental changes in the very institutions that empower us to speak and work. (Alcoff \& Potter 1993, 13-14)

In my understanding, what Alcoff and Potter are asking for is caring for difference so that a difference is made there where difference seems to have no place, there where difference is improbable, namely in the production of knowledge. Difference is requested as an antidote - beware, not to objectivity, but to Certainty, which holds together the one Epistemology grounded in Metaphysics and in the paradigm of modern rationalist and positivist science.

Alcoff and Potter clearly establish a link between the ontological, the epistemological, and the ethico-political aspects and consequences that Feminism and/in the/its plural opens up when the challenge thereby implied is assumed.

To raise a question regarding Feminism and the plural shows both the desire and the need for a plural conceptualization of Feminism.

To situate Feminism in the plural implies a claim for a plural articulation of Feminism.

To stress a look at Feminism and its plural speaks of the will to recognize what kind of relation Feminism is able to establish to the plural or to what extent Feminism is open to become plural.

Finally, to ask about Feminism in its plural entails the challenge to find the way for Feminism to look for its specific plural, to specifically care for it and stand by it. The quest for complexity as an antidote against simplification runs parallel to the quest for specificity. In my opinion, the specific plural of Feminism by means of which difference and the care for difference most radically applies points at the Body. I shall dwell upon the Body and its role regarding the specificity of difference, to which I am referring here, in the forthcoming paragraphs. However, I want to underline with no further delay that difference operates as a structure at very different levels, yet always in material terms in that - as we have learned from Black and Post - and Decolonial, but also Marxist Feminisms - difference primarily concerns the material conditions of the lives of the subjects. Therefore, I suggest, difference cannot - and should not - be reflected upon without the Body. 
It goes without saying that Plurality is and remains a challenge for nowadays Feminism. Caring for difference brings Feminism on the stands of Plurality. I suggest that we briefly pay attention to what I take to be the main ways in which this challenge conforms itself as ways of caring for difference and standing for transformation, including self-transformation. Univocal signification, hegemony, and self-affection comply with the logic of the Mass. I believe that by taking on the challenge of Plurality, univocal signification becomes ambiguity, hegemony becomes contingency, and self-affection becomes hetero-affection. Let us try to go one by one through each transformation. Nonetheless, let me just note that Feminism is hereby facing a structural transformation, meaning thereby that a logic, as I already brought attention to, namely, the static logic of the One, undergoes thereby transformation as well.

The logic of the One, of the Mass, is fundamentally an all-encompassing or literally totalitarian logic of calculation, of measure, and of control. Feminism and/ in the/its plural brings about a new logic or, rather, it brings about that which is new into logic, the unexpected, the improbable, and therein lies the transformative power of Feminism, which indeed enables and enacts the power of difference. In this way, Feminism brings about a change of paradigm just as Quantum Physics actualizes by means of uncertainty, superposition and entanglement as its main operative principles, a change of paradigm in the realm of Science in relation to classic Physics.

Now, in the context of Feminism today, what does the transformation of univocal signification into ambiguity entail and bring about? What does the transformation of hegemony into contingency entail and bring about? Finally, what does the transformation of self-affection into hetero-affection entail and bring about?

We need to look at the Body in order to take on these questions. We need to look at the Body since the Body is at once the discursive and the material site of difference understood as an embodied and non-dialectical tension, therefore not fully mediated, between the universal and the singular. We need to look at the Body in order to make operative difference as sexual difference. The Body, I state, paradigmatically performs Plurality in the terms Hannah Arendt points out, that is, as a structural discrepancy within sameness, since we humans are, in her view, the same and uniquely never the same at once. This structural discrepancy is what the Body paradigmatically enacts by the work of sexual difference, that here can be understood as an operation of an ontological, epistemological, and ethico-political scope and significance.

In «Bodies and Knowledges: Feminism and the Crisis of Reason», included in Feminist Epistemologies. Thinking Gender, Elizabeth Grosz points out the ontological, epistemological, and ethico-political need to take into account what she names as «explicit sexualization of knowledge» (Grosz 1993, 187). This is relevant in order to make evident that knowledge is partial and not neutral even if, as it usually is 
maintained in the name and for the sake of objectivity, it is articulated according to the parameters of instrumental or enlightened rationality, which, as we know since Descartes, dismisses the Body, the res extensa, as a source of Certainty. However, Grosz is not - as it is the case with Judith Butler - referring to the Body from the point of view of gender, a point of view that offers, as we know, an exclusively discursive approach to the Body. In Elizabeth Grosz's view, sex, that is, sexual difference, is the reference, yet a non-discursive reference, since it becomes a rationale of its own, a radically singular rationale by means of which the new, the unexpected, and the improbable that only the Body brings about, transforms neutrality in ontological, epistemological, and ethico-political terms.

Feminism is thereby encouraged to render operative sexual difference as rationale, the main operation of which is none other than precisely difference, the actualization, that is, the materialization, time and again, of difference. This situates us in a radically other form of logic than the logic of the One, which is, as mentioned previously, a logic of calculation, of measure, and of control.

We are little by little touching upon the complexity of Feminism I have approached at the beginning of this paper. The title of the paper, I have stated, bears witness to complexity. Indeed, it bears witness to the complexity of this other logic, this radically singular rationale that is sexual difference and to the challenge therein implied.

(1) Univocal signification - ambiguity (plurality)

For how is it possible to renounce to univocal signification, or even to critically speak out against it, to devote enunciation to ambiguity, and yet still have an effect on society? How is it possible to honor the plural, and this means to honor every single one of the differing voices of Feminism, and still contribute to activism? Furthermore, how is it possible to explicitly avoid mediating other voices and still stand up against injustice, discrimination, exclusion, exploitation, etc.? I refer here to the challenge Gayatri Spivak posed to white European Feminism already in 1988 with her article «Can the Subaltern Speak?», but also to the new methodological frame which Kimberlé Crenshaw introduced one year later, in 1989, with her notion of intersectionality, just to mention two well-known critical approaches of univocal signification. I am also thinking of a debate which took place several years ago in Barcelona and in Spain about the legalization of sexual work and, specifically, about the creation of a trade union for female sex workers which would allow them to visibly fight for their social rights.

Is there one voice of Feminism? Furthermore, to phrase it more dramatically, is there one single entitled voice of Feminism? To my understanding, what these women, what these feminists, among others, make evident is that there is no such thing as a single entitled voice of Feminism, nor should there be. In other words, there is not a true Feminism, a source of legitimacy, by means of which a kind of original essence is kept as a treasure in a saving box. Feminism is a movement; it 
is a collective movement, a deeply heterogeneous movement. Feminism is a flux, a running and changing river, a coincidence of a variety of intensities, and this means that it differs from within, intrinsically, and that, at the same time, it differs from other movements which are fundamentally based in the One, this One being for instance individual rights. This all means that, to renounce critically to univocal signification implies that mutual belonging and interdependency shape the discourse as well as the action of Feminism, and that no hierarchy is hereby at work nor allowed. It is from this anti-hierarchical perspective that I agree with Judith Butler, among many other voices now, when she claims that transphobic Feminism is no Feminism. Because transphobic Feminism does not care for transrealities in the sense that it does not care for difference and that it does not stand by it.

(2) Hegemony - contingency (indetermination)

It seems rather obvious that the disavowal of univocal signification as a regulatory operation of enunciation that allows for a hierarchical legitimation of a particular discourse above others implies the destabilization of hegemony understood as institutionalized power supremacy. Therefore, as Gramsci pointed out, in any political scenario, the fight for power entails a hegemony contest, which is driven by the dissemination of, and later consent to, ideas that sooner or later become commonsensical and, thereby, become an obstacle for other ideas to evolve and shape the political arena.

What is interesting here, because it makes evident that Feminism indeed cares for difference as rationale, is that the destabilization of hegemony - maybe this would be a way of conceptualizing revolutions in contemporary terms - does not need to be carried out in order to win it, and consequently to tip over into a new hegemonic position. In my opinion, Feminism does not claim hegemony for itself when it engages with difference. An example of this is the movement Marea Verde in Argentina, leading the demand for free abortion in the country, or the newest feminist wave in Chile, denouncing the silenced and reiterated patriarchal abusive practices of harassment in higher education centers all over the country that we saw in full action in the summer of 2018. Both feminist initiatives clearly acted upon structural patterns of what we know as capitalist patriarchy in Silvia Federici's terminology. Yet neither one claimed a hegemonic position. This implied, for instance, that they did not take a formal step into institutionalized politics they did not conform to any political party - and they were highly and broadly criticized for not doing so even by supposedly progressive female politicians.

When difference matters, difference instead of this or that idea, difference instead of this or that individual, difference instead of this or that right or all along with all of it in a structural way; when difference leads the fight, the fight for that which is new, for the unexpected, for the improbable, then hegemony is ruled out. Contingency, on the other hand, is fully operative. 
Hannah Arendt understands action, political action, transformative action, in terms of unpredictability, which is related to contingency in the sense that it binds action to a logic where calculation, measure, and control are also ruled out. In this respect, she writes: «The reason why we are never able to foretell with certainty the outcome and end of any action is simply that action has no end» (Arendt 1989, 233). Action escapes the logic of causality because it is "boundless», she states. Therefore, «the smallest act in the most limited circumstances bears the seed of the same boundlessness, because one deed, and sometimes one word, suffices to change every constellation» (Arendt 1989, 190).

What matters is to allow difference to evolve and shape the political arena, in a way that the new, the unexpected, and the improbable happen and literally take place.

(3) Self-affection - hetero-affection (affection)

Affection has become a gigantic issue for Feminism in the recent times. It is not my purpose here to go through the significant variety of forms it has taken in the relatively recently named affect theory. Yet what is common to all of those forms is that they expand on Spinoza's - the $17^{\text {th }}$ century outsider philosopher - understanding that affects and action condition one another. Action derives in any living being from affection because all living beings strive after perseverance. Spinoza understands that affection provides all living beings with a power - potentia - that enables them to act, and the fundamental power all living beings are endowed with is precisely the power to persevere. Spinoza names this power conatus. The main point here is that Spinoza allows for the new, the unexpected, and the improbable to take place in philosophical discourse in the context of Ethics as the ruling force of action. This calls us into a very different scenario than the one Descartes built for the res cogitans. It also calls us into a very different scenario than the one occupied by the Mass, since the Mass is affectless, or, rather, indifferent, just like das Man as opposed to Dasein, since, according to Heidegger, the existence of Dasein structurally rests on care. Care is indeed the main existentiary in Sein und Zeit.

Now, if we agree that Feminism cares for difference, for sexual difference as the radical expression of a difference - a distance - «in front of the others», in Heideggers's words, then we can affirm that Feminism is an affective movement in the sense that it is a movement of affects. Feminism allows for a circulation of affects, a plurality of affects inasmuch as it allows, as we have seen, for a plurality of voices and for a plurality of causes. Yet, what is relevant here is that difference is and remains cared for. This means that difference, that is, the material and nondialectical tension it consists of, remains as such inasmuch as the other remains as such or as singularity remains as such. Mediation does not occur and the other, the other affect, the other voice, the other cause remains other, remains in difference. Self-affection is not without the other, without the affection by the other, and without this affection remaining other. There is no affection without a structural 
distance, no care without a structural difference. This is how affection is and remains hetero-affection, and it is also how Feminism avoids indifference.

In my view, the challenge for Feminism is and remains to persevere in the commitment to allowing the movement to differentiate from itself, to persevere not simply in the plural, but singularly in its plural.

From the point of view of hetero-affection, but also from the point of view of ambiguity and contingency, the challenge of difference for Feminism has ontological, epistemological, as well as ethico-political consequences of great relevance. Not only because collective action becomes detached from a universal or general ideal or expectation, from a universally valid rule or program, which, for instance, in terms of decolonizing Feminism proves to be crucial, but even more strongly, because it makes Feminism at once familiar and strange to itself.

I agree with Teresa De Lauretis when she underlines in an article published in 1990 and entitled «EccentricSubjects: Feminist Theory and Historical Consciousness» that dealing with difference - she speaks of self-criticism - results in a permanent exile, since the subject is obliged to renounce to a «home.» I find her observation very similar to the former quotation by Audre Lorde about «the house of difference.» Difference happening, taking place, materializing in discourse, leads Feminism to abandon "physically, emotionally, linguistically, and epistemologically - that home - for some other unknown and risky place, which is not other only emotionally but also conceptually, for a discursive place from which talking or thinking is tentative, insecure and with no guarantee» (De Lauretis 1990, 138). What De Lauretis is describing here, in tune with Arendt's revolution, is a radical experience of permanent «dis-identification» (De Lauretis 1990,139) as the key experience or even as the experience sine qua non for the ongoing transformation, first of all, of Feminism itself.

\section{References}

Alcoff, Linda, and Elizabeth Potter (eds.). 1993. Feminist Epistemologies. Thinking Gender. London: Routledge.

Arendt, Hannah. 1989. The Human Condition. Chicago. The University of Chicago Press.

Arendt, Hannah. 1990. On Revolution. London: Penguin Books.

Crenshaw, Kimberlé. 1991. «Mapping the Margins: Interseccionality, Identity Politics, and Violence against Women of Color.» Standford Law Review, 43: 1241-1299.

De Lauretis, Teresa. 1990. «Eccentric Subjects: Feminist Theory and Historical Consciousness.» Feminist Studies 16(1): 115-150. DOI: 10.2307/3177959

Grosz, Elizabeth. 1993. «Bodies and Knowledges: Feminism and the Crisis of Reason.»In Feminist Epistemologies. Thinking Gender, edited by Linda Alcoff and Elizabeh Potter, 187-216. London: Routledge.

Heidegger, Martin. 2010. Being and Time. Translated by Joan Stambaugh, revised by Dennis J. Schmidt. Albany, New York: SUNY Press. 
Lorde, Audre. 1985. Zami: A New Spelling of my Name. New York: Quality Paperback Book Club.

Spivak, Gayatri. 1988. «Can the Subaltern Speak?» In Marxism and the Interpretation of Culture, edited by Cary Nelson and Lawrence Grossberg. London: Macmillan.

Begonya Saez Tajafuerce. Professor of Philosophy at the Universitat Autònoma de Barcelona and, since 2005, member of the Group Body and Textuality at the same university. Since 2001, her research has focused on identity in contemporary terms. She works on feminist approaches to the Body from a relational standpoint and from an ontological, epistemological, ethical and political perspective. The following are some of her most recent publications: Debats: Un corpus para el cuerpo (2013), Cuerpo, memoria y representación: Adriana Cavarero y Judith Butler en diálogo (2014) y Feminismos en la era del algoritmo (2019).

Electronic address: Begonya.Saez@uab.cat

Article received on the 17th of July and accepted for publication on the 7th of October 2020. 
